\title{
Non-destructive methodology in comparative physiology of buckwheat genotypes within the different origin
}

\author{
Oksana SYTAR ${ }^{1,2}$, Klaudia BRUCKOVA ${ }^{1}$, Alyona PLOTNITSKAYA ${ }^{3}$, Marek ZIVCAK ${ }^{1}$, \\ Marian BRESTIC ${ }^{1}$ \\ 1 Department of Plant Physiology, Slovak University of Agriculture, Nitra, A. Hlinku 2, 94976 Nitra, Slovak Republic \\ 2 Plant Biology Department, Taras Shevchenko National University of Kyiv, Institute of Biology, Volodymyrska str., 64, Kyiv \\ 01033, Ukraine \\ ${ }^{3}$ Laboratory of Quality and Safety of Products of Agro Industrial Complex. Mashynobudivnykiv Street Building 7, Chabany \\ village, Kyiv-Svyatoshinsky district, Kyiv region, 08162, Ukraine
}

E-mail address of corresponding author:

Oksana SYTAR: oksana.sytar@gmail.com

Coauthors:

Marek ZIVCAK, email: marek.zivcak@uniag.sk, Alyona PLOTNITSKAYA, email: pl_av@ukr.net,

Klaudia BRUCKOVA, email: klaudia.bruckova@gmail.com, Marian BRESTIC, email: marian.brestic@uniag.sk

DOI https://doi.org/10.3986/fag0007

Received: March 14, 2019; accepted: May 25, 2019

Keywords: chlorophyll fluorescence, phenolic acid, non-destructive measurement, flavonoids, anthocyanins

\begin{abstract}
In the presented study has been used non-destructive method for prescreening of flavonoids, anthocyanins and pigments from early stage of growth till flowering period of buckwheat genotypes of different origin. The similar increasing tendency in the changes of FLAV, ANTH and MFI indexes of Chinese genotypes compared to the tendency of Ukrainian genotypes has been observed. Genotypes of F. tataricum compared to the genotypes of F. esculentum have been shown to lower ANTH index during seedling growth. SFR index which relates to chlorophyll concentration shown different dynamic between Ukrainian and Chinese genotypes. In the middle phase 30 days after sowing (DAS) of growth has been discovered significant increase of SFR index almost in all experimental genotypes. On 36 DAS just two Ukrainian genotypes which characterized also high ANTH and MFI indexes has been kept tendency to increase SFR index. HPLC analysis of experimental samples found that presence of p-anisic acid was typical for F. tataricum species compared to the experimental cultivars of F. esculentum of both origin. Buckwheat genotypes of different origin can vary in flavonoid, anthocyanins and pigments content during stages of growth, but changes in their contents can be similar for representatives of the same origin.
\end{abstract}




\section{INTRODUCTION}

The Food and Agriculture Organization of the United Nations (FAO) supposes that the world's population in 2050 will be 34\% greater than it is today. Currently, 49\% of the world's population lives in urban areas, while in 2050 this will be closer to 70\% (Alexandratos and Bruinsma 2012). During this time period, climate change and the development of biofuel production will present major risks to long-term food security. Population growth, urban civilization and climate change can effectively support high crop concurrence as possible sources of food, bioenergy, fiber and other industrial needs. Going forward, these problems will require innovative approaches to the genetic and agronomic components of systems of crop production and developing concurrent food market.

While we are entering a period of increasingly rapid climate change, the overall objective of the project initiative is to design new strategies to maintain high yield and qualitative parameters of crop plants produced under changed environmental conditions, using novel crop plants which is promising for development in food market. Crop yield is a complex trait depending on the successful completion of different steps of vegetation (phase of reproductive organ development), which can be sensitive to environmental factors.

Among innovative approaches is high interest in plant biotechnology and non-destructive methods of prescreening agriculture plants regarding content of specific secondary metabolites, regarding development of some diseases, stress reaction for the missing of nitrogen supply or to discover plant species biodiversity. In targeted plant metabolites, the main goal is to achieve a high throughput. Therefore, there is often an initial desire for a rapid pre-screening of the samples. This is especially the case when dealing with many sample numbers, where only a limited number of individuals might be expected to be different (Verhoeven et al. 2006). This is the case when searching for valuable genetic resources (e.g. those having a high content of desired compounds) within natural populations or population obtained by crosses or mutagenesis (Sytar et al. 2015; 2017).

Nowadays many scientific groups in the functional food area are looking for plants with high content of phytochemicals as an important source of active pharmaceuticals or with valuable nutritional properties (Abuajah et al. 2015; Varzakas et al. 2016). Buckwheat among these plants got a prime position as potential source of gluten free food products as well as rich source of antioxidant compounds (Saturni et al. 2010). The various types of bioactive compounds presented in different buckwheat varieties provide basic background needed for the efficient production of buckwheat foods with added value (Sytar et al. 2016). Two main buckwheat species have been commonly produced and consumed: common buckwheat (Fagopyrum esculentum Moench) and Tartary buckwheat (Fagopyrum tataricum Gaertn). The biodiversity of buckwheat plant species which can be used farther are wide. Therefore, its is important to develop study difference between buckwheat species of different origin.

The non-invasive fluorescence-based phenomics method for determination of plant phenolics based on the strictly UV-absorbing properties, the effects of phenolic compounds on visible light-induced chlorophyll fluorescence is negligible, whereas their presences strongly suppress the chlorophyll fluorescence emission under UV excitation (Cerovic et al. 2002). This phenomenon has been successfully applied for estimation of transmittance of UV radiation by chlorophyll fluorescence (Burchard et al. 2000; Ounis et al. 2001). In the previous decades, the numerous studies examined and confirmed possibility to use the chlorophyll fluorescence signal in the estimation of phenolics and anthocyanins. In addition to self-constructed devices or standard fluorometers combined with external light sources and filters, which were used in the majority of studies, the factory-made special devices for this purpose were also introduced (Sytar et al. 2015).

In this scientific work we would like to combine the non-invasive fluorescence-based, and traditional biochemical methods (HPLC, spectrophotometry etc.), typically used for plant phenomics studies to discover growth characteristics of buckwheat species of different origin.

\section{MATERIAL AND METHODS}

\section{Plant material}

Plants of 7 buckwheat samples from Ukraina ( $F a-$ gopyrum tataricum himalaicum, Faropyrum tataricum rotundatum - red, Fagopyrum esculentum cv. Rubra - red, Fagopyrum esculentum cv. Karadag) and Chinese cultivars (Fagopyrum esculentum cv. SuQiao 1, Fagopyrum esculentum cv. YuQiao 4, Fagopyrum esculentum cv. NingQiao 1) were exposed immediately from sowing to direct sunlight in open field conditions for 52 days. The non-destructive measurements were started from early growth stage (stage of vegetation). First measurements were done at 
stage of two leaves (22 days after sowing (DAS)), other measurements were carried out at stage of 4-5 leaves (30 DAS), at the beginning of flowering stage when buckwheat plants had 5-6 leaves (36 DAS) and last measurements were done in flowering stage (51 DAS). The leaves for biochemical analysis were collected in the flowering phase.

Cultivar Rubra with high anthocyanins content (3.87-4.41 mg/100 g DW) in the vegetative organs has been received by family selection method from chemo mutants. Cultivar Karadag is received from the Scientific Research Institute of Groat Crops in Ukraine. F. tataricum $\mathrm{G}$. is a one-year plant which, among the species researched, has a better pollination of flowers and a higher grain production. F. giganteum Krot. is amphidiploid obtained after crossing F. tataricum G. with the perennial plant F. cymosum Meissn. (Krotov and Dranenko 1973). F. cymosum Meissn. is a polyploid with 32 chromosomes. The collection of buckwheat germplasm, which is maintained at the Scientific Research Institute of Groat Crops in Ukraine comprises nearly 1000 samples which are readily available for breeding research.

\section{Chlorophyll fluorescence records and analyses using fluorescence excitation ratio method}

The chlorophyll fluorescence analysis was done using the portable optical fluorescence sensor Multiplex- $3^{\circledR}$ (Force-A, Paris, France). Multiplex- $3^{\circledR}$ is a hand-operated, multi-parametric sensor based on light-emitting-diode excitation and filtered photodiode determination that is arranged to work in the field, greenhouse and laboratory conditions. The sensor of Multiplex- $3^{\circledR}$ has three, redblue-green LED-matrices emitting light at $470 \mathrm{~nm}$ (blue), $516 \mathrm{~nm}$ (green) 153 and $635 \mathrm{~nm}$ (red). There are three integrated photodiode detectors for fluorescence recording: far-red, red and yellow (Ghozlen et al. 2010). We used values of fluorescence measured at UV (375 nm), green light (516 nm), red light (635 nm) and $735 \mathrm{~nm}$ (FRF).

The evaluation of phenolic compounds contents in plants was done via calculation of fluorescence values detected after excitation by light of the defined wavelengths (details are below). In analogy to the spectrophotometric method for assessing leaf absorbance, the parameters were based on the Beer-Lambert's law and calculated as logarithm of the fluorescence ratio values.

UV absorbing compounds (mostly flavonols) content described by flavonoid (FLAV) index (Cerovic et al. 2002; Agati et al. 2011) was estimated using the modified for- mula of Zivcak et al. (2017), as the logarithm of the ratio of the red-light induced far-red fluorescence $\left(\mathrm{FRF}_{\mathrm{R}}\right)$ and the UV-induced far- red fluorescence $\left(\mathrm{FRF}_{\mathrm{UV}}\right)$ :

$$
\mathrm{FLAV}=\log \left[\mathrm{FRF}_{\mathrm{R}} /\left(\mathrm{k}_{\mathrm{UV}}{ }^{*} \mathrm{FRF} \mathrm{UV}_{\mathrm{UV}}\right)\right]
$$

Similarly, the ANTH Index that provides estimates of green-light absorbing compounds $\left(\log \mathrm{FER}_{\mathrm{R} / \mathrm{G}}\right)$, mostly red-colored flavonoids and anthocyanins, was calculated as the logarithm of the ratio of the red- light induced fluorescence $\left(\mathrm{FRF}_{\mathrm{R}}\right)$ and the green light-induced fluorescence $\left(\mathrm{FRF}_{\mathrm{G}}\right)$ :

ANTH $=\log \left[\mathrm{FRF}_{\mathrm{R}} /\left(\mathrm{k}_{\mathrm{G}}{ }^{*} \mathrm{FRF}_{\mathrm{G}}\right)\right]$

The correction coefficients $\mathrm{k}_{\mathrm{UV}}$ or $\mathrm{k}_{\mathrm{G}}$ was applied to measurements of fluorescence to avoid negative values (Zivcak et al. 2017). The constant values of the coefficients were used as the minimum values of the $\mathrm{FRF}_{\mathrm{UV}}$ / $F R F_{R}$ and $F R F_{G} / F R F_{R}$ ratios found in the database that contains several thousand records from over three hundred plant species grown in diverse environments (Zivcak et al. unpublished results). The same constants have been used when processing data across all experiment and cultivars. We also calculated the modified Flavonoid Index (MFI) that provides a better estimate of total flavonoid content when plants with different colors are compared (Zivcak et al. 2017). The MFI was calculated as the logarithm of the ratio of the red-light induced fluorescence $\left(F R F_{R}\right)$ and the green light-induced fluorescence $\left(\mathrm{FRF}_{\mathrm{G}}\right)$. MFI $=\log \left[2^{*} \mathrm{FRF}_{\mathrm{R}} /\left(\mathrm{k}_{\mathrm{G}}{ }^{*} \mathrm{FRF}_{\mathrm{G}}+\mathrm{k}_{\mathrm{UV}}{ }^{*} \mathrm{FRF}_{\mathrm{UV}}\right)\right]$

The values of correction coefficients $\left(\mathrm{k}_{\mathrm{G}}, \mathrm{k}_{\mathrm{UV}}\right)$ for MFI were the same as for ANTH and FLAV.

Chlorophyll content was estimated from values of fluorescence measured at $735 \mathrm{~nm}(\mathrm{FRF})$ and at $685 \mathrm{~nm}$ (RF) after excitation by red light (635 nm). The Simple fluorescence ratio (SFR) was calculated as:

$\mathrm{SFR}=\mathrm{FRF}_{\mathrm{R}} / \mathrm{RF}_{\mathrm{R}}$

Because the diameter of the measuring area was only $50 \mathrm{~mm}$, 6-7 measurements were taken on each plant in different position to account for heterogeneity in leaf color and structure. This number of measurements from the top view provides sufficient data to characterize the entire plant.

\section{Anthocyanins estimation}

0.1 - 0.5 g plant material was homogenized on ice with $3 \mathrm{ml}$ of acidified methanol $(1 \% \mathrm{HCl})$ and then incubated at $4{ }^{\circ} \mathrm{C}$ for $12 \mathrm{~h}$ with moderate shaking. The mixture was centrifuged for $10 \mathrm{~min}$ at $14000 \mathrm{rpm}$ at $4{ }^{\circ} \mathrm{C}$. Absorbtion of the extracts at 530 and $657 \mathrm{~nm}$ wavelengths was determined spectrophotometrically. The blank was acid- 
ified methanol. The concentration of the anthocyanins was expressed as mg.g $\mathrm{g}^{-1}$ dry weight and was calculated by formula:

anthocyanins $=\left[\mathrm{A} 530-\left(0.25^{*} \mathrm{~A} 657\right]^{*} \mathrm{~V} /\left(\mathrm{W}^{*} 1000\right)\right.$,

where $\mathrm{A}$ is absorbance; $\mathrm{V}$ is total volume of the extract $(\mathrm{ml})$ and $\mathrm{W}$ is weight of the dry leaf tissue $(\mathrm{g})$.

\section{Total phenolics estimation}

Total phenolic content in the buckwheat leaves extracts was determined by standard spectrophotometric method of Lachman et al. (2003) by using Folin-Ciocalteu reagent (Singleton and Rossi, 1965). 0.25 g powdered samples (freeze-dried) was extracted for 16-18 hours with $20 \mathrm{ml}$ of $80 \%$ ethanol. After the time of extraction a volume of $100 \mu \mathrm{l}$ of the plant extract was pipetted into 50 $\mathrm{ml}$ volumetric flask. $2.5 \mathrm{ml}$ of Folin-Ciocalteau reagent was added to the extract. Then after 3 minutes (agitation) $5 \mathrm{ml} 20 \% \mathrm{Na}_{2} \mathrm{CO}_{3}$ solution was mixed. After two hours at $25{ }^{\circ} \mathrm{C}$ the absorbance was measured on the spectrophotometer Jenway UV/Vis 6405 (Jenway, UK) at wavelength $\lambda=765 \mathrm{~nm}$ against blank. Gallic acid was used as a reference standard for plotting calibration curve. Total phenolic content was expressed as $\mathrm{mg} \cdot \mathrm{kg}^{-1}$ gallic acid equivalent of dry matter.

\section{Analysis of hydroxycinnamic acid derivatives}

Analysis of hydroxycinnamic acid derivatives has been previously developed (Mewis et al. 2010). Samples were taken after finishing the freeze-drying process where the material was ground by a flint mill (20 $000 \mathrm{~g}$ for $2 \mathrm{~min}$ ). A total of $20 \mathrm{mg}$ ground samples from leaf suspension were extracted for $15 \mathrm{~min}$ using $0.75 \mathrm{~mL} 70 \%$ methanol (v/v, pH 4.0, phosphoric acid) in an ultrasonic water bath on ice. Then samples were centrifuged for 5 $\mathrm{min}$ at $6000 \mathrm{rpm}$. The supernatants were collected and the pellets were re-extracted twice more with $0.5 \mathrm{~mL}$ of 70\% methanol (HPLC-Gradient grade, VWR chemicals). Coumaric acid or cinnamic acid (Sigma-Aldrich Chemie $\mathrm{GmbH}$ ) (40 $\mu \mathrm{L}$ of $3 \mathrm{mM}$ solution) was added as internal standard to the first extraction. The combined supernatants from each sample were reduced to near dryness in a centrifugation evaporator (Speed Vac., SC 110) at $25^{\circ} \mathrm{C}$.

Samples were added up to $1 \mathrm{~mL}$ with $40 \%$ acetonitrile (HPLC Ultra Gradient Grade, Roth). The samples were filtrated using $0.22-\mathrm{mm}$ filters and then analyzed with HPLC. The chromatography was performed using a DionexUltiMate 3000 HPLC System with a diode array detector (DAD-3000) with a WPS-3000 SL auto sampler,
LPG-3400SD pump and a TCC-3000RS Column Compartment (Dionex Corp., Sunnyvale, CA, USA).

Extracts $(1 \mathrm{~mL})$ were analyzed at a flow rate of $0.4 \mathrm{~mL} /$ min and a column temperature of $35^{\circ} \mathrm{C}$. The column used is Narrow-Bore Acclaim PA C16-column (3 mm, 120A, 2.1 _ $150 \mathrm{~mm}$, Dionex). A 49-min gradient program was used with $0.1 \% \mathrm{v} / \mathrm{v}$ phosphoric acid in ultrapure water (eluent A) and $40 \% \mathrm{v} / \mathrm{v}$ acetonitrile in ultra-pure water (eluent B) as follows: $0-5$ min: $0.5 \%$ B, 5-9 min: 0-40\% B, 9-12 min: 40\% B, 12-17 min: 40-80\% B, 17-20 min: 80\% B, 20-24 min: 80-99\% B, 24-32 min: 99-100\% B, 32-36 min: $100-40 \%$ B, 36-49 min: 40-1\% B. The gradient program was followed by a 4-min period to return to $0.5 \% \mathrm{~B}$ and a 5-min equilibration period resulting in a total duration of 39 min. Peaks were monitored at 290, 330 and 254 $\mathrm{nm}$ respectively. The phenolic acid quantity was calculated from HPLC peak areas at $290 \mathrm{~nm}$. The retention times in the HPLC for the experiments were 12.13 min for vanillic acid, $12.72 \mathrm{~min}$ for chlorogenic acid, $13.29 \mathrm{~min}$ for caffeic acid, 15.98 min for the internal standard p-coumaric acid and 21.59 min for cinnamic acid. For the identification of unknown phenolic compounds, a semiquantitative analysis was performed using HPLC coupled with mass spectrometric detection (LC/MS) and NMR (Mewis et al., 2010).

\section{Statistical analysis}

Means and standard deviations were calculated by the Microsoft Office Excel 2013. Significant differences of these data were calculated using analysis of variance ANOVA Duncan's multiple test (STATISTICA 10, StatSoft, Tulsa, USA). All results were expressed as mean+ standard deviations from replications $\mathrm{n}=50$.

\section{RESULTS AND DISCUSSION}

\section{Chlorophyll fluorescence records and analyses of FLAV, ANTH, MFI and SFR indices using fluorescence excitation ratio method}

Chlorophyll fluorescence records and analyses using fluorescence excitation ratio method of Ukrainian and Chinese genotypes during growth periods of 51 DAS shown significant increasing of FLAV index from beginning of seedlings stage to the of flowering stage (Fig.1).

The highest increase of FLAV index which is connected with flavonols content has been observed in the Chinese genotypes. The high FLAV index at the flowering stage was not depended from flavonols content on 


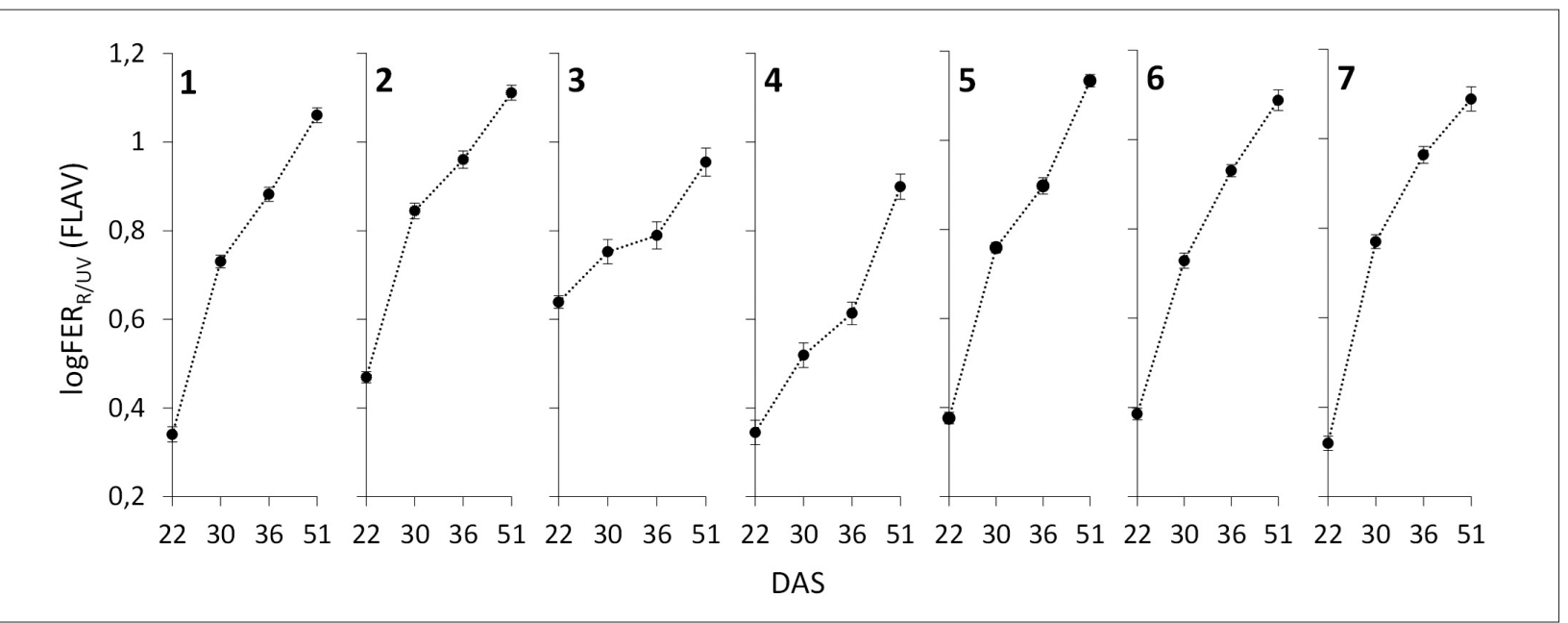

Figure 1. Process of flavonols accumulation (logFER $\left.R_{R / U V}-F L A V\right)$ in the leaves of investigated buckwheat plant species exposed to direct sunlight during 51 days after seedlings (numbers indicate individual cultivars of buckwheat as follow: 1 - F. tataricum rotundatum, 2 - F. tataricum himalaicum, 3 - F. esculentum cv. Rubra, 4 - F. esculentum cv. Karadag, 5 - F. esculentum cv. SuQiao 1, 6 - F. esculentum cv. YuQiao 4, 7 - F. esculentum cv. NingQiao 1).

the beginning of seedlings stage (22 DAS). For example, Ukrainian genotype F. esculentum cv. Rubra on 22 DAS has a highest FLAV index (0.64 RU) compared to other experimental genotypes. At the flowering stage on 51 DAS FLAV index in this experimental genotype was 0.95 RU which was lower compared to the other experimental genotypes. Plus other Ukrainian genotype F. esculentum cv. Karadag on the beginning of seedlings stage (22 DAS) got FLAV index $0.35 \mathrm{RU}$ which was similar to the level of FLAV index of Ukrainian F. tataricum rotundatum and Chinese F. esculentum cv. SuQiao 1, 6 - F. esculentum cv. YuQiao 4, 7 - F. esculentum cv. NingQiao 1. At the flowering stage on 51 DAS FLAV index in these experimental genotypes was in range 1.06-1.13 RU.

The different tendency of ANTH index increasing from beginning of seedlings stage to the flowering stage

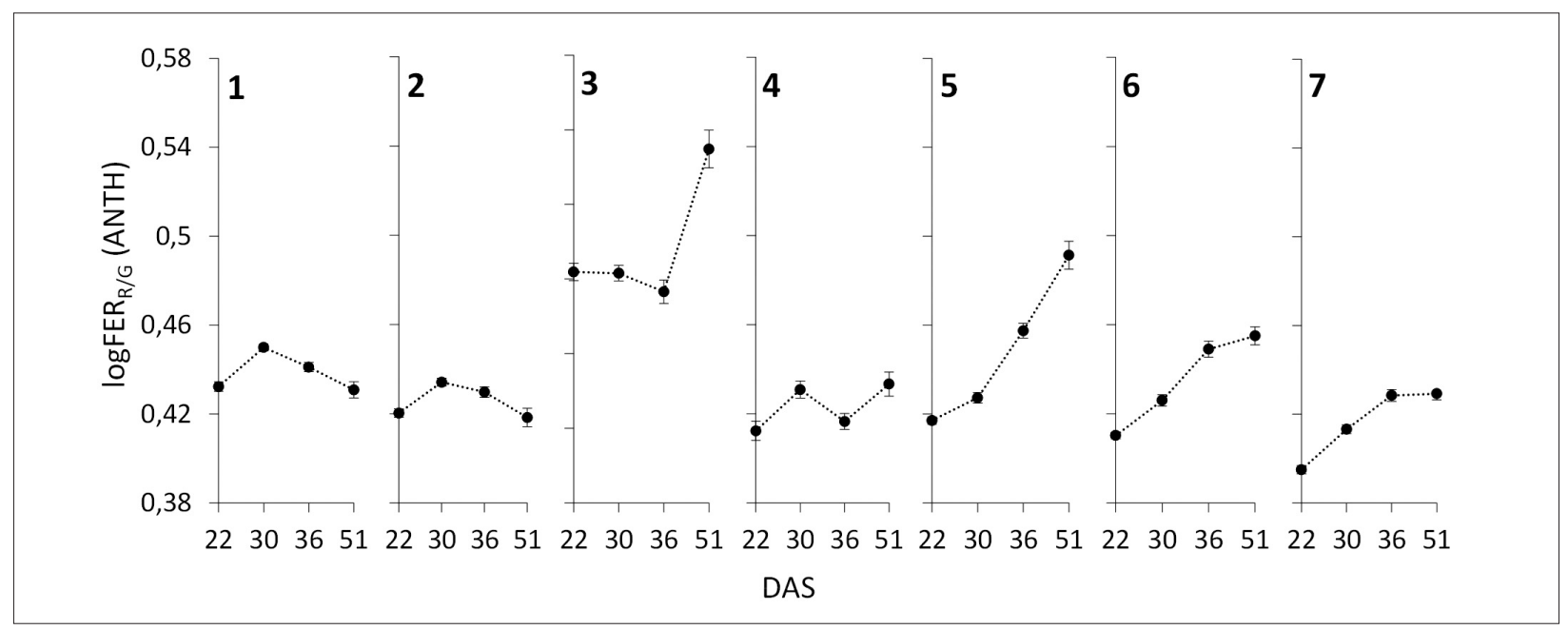

Figure 2. Process of anthocyanins accumulation $\left(\log F E R_{R / G}-A N T H\right)$ in the leaves of investigated buckwheat plant species exposed to direct sunlight during 51 days after seedlings (numbers indicate individual cultivars of buckwheat as follow: 1 - F. tataricum rotundatum, 2 - F. tataricum himalaicum, 3 - F. esculentum cv. Rubra, 4 - F. esculentum cv. Karadag, 5 - F. esculentum cv. SuQiao 1, 6 - F. esculentum cv. YuQiao 4, 7 - F. esculentum cv. NingQiao 1) 
Sytar et al., (2019): Methodology in comparative physiology of buckwheat

has been observed for Ukrainian genotype F. esculentum cv. Rubra compared to other investigated buckwheat plant genotypes (Fig. 2). At the beginning of seedlings stage this genotype has highest ANTH index (0.50 RU) and at the flowering stage on 51 DAS (0.57 RU) too. At the flowering stage came to significant increase of ANTH index in F. esculentum cv. Rubra, on the contrary to other Ukrainian genotypes $F$. tataricum rotundatum and F. tataricum himalaicum, in which has ANTH index decreasing character from beginning of flowering stage. On the 51 DAS at the flowering stage in F. tataricum genotypes ANTH index was almost on the same level as at the beginning of seedlings growth after significant increasing at the 30 and 36 DAS. ANTH index for other investigated genotypes (was) ranged from 0.39 to $0.43 \mathrm{RU}$ at the beginning of seedlings stage. Genotypes of F. tataricum compared to the genotypes of $F$. esculentum of both origin shown decreasing of ANTH index during seedling growth. All F. esculentum genotypes of both orgin has inceasing on ANTH index on 51 DAS (Fig.2).

MFI, the parameter that takes into consideration the accumulation of both flavonols and anthocyanins, is a better estimate of flavonoids than FLAV (Zivcak et al., 2017). Results of statistical analyses using MFI are highly similar to those that use data of biochemical analysis (Zivcak et al., 2017). MFI index did not shown significant difference between F. tataricum and F. esculentum genotypes of both origin but highest values has been found for F. esculentum cv. Rubra during all growth stages. Based on the obtained prescreening results during 51 DAS of growing period is possible to conclude that non-destructive methodology can be used to choose genotypes with high antioxidant content.

The majority of published vegetation indices for non-invasive remote sensing techniques are not sensitive to rapid changes in plant photosynthetic status brought on by common environmental stressors. The SFR index is connected with chlorophyl concentration in the leaves. In presented experiment with buckwheat genotypes of different origin the tendency of SFR index changes was different between genotypes of Ukrainian and Chinese origin (Fig.4). In the middle phase (30 DAS) of growth has been observed significant increase of SFR index almost in all experimental genotypes. On 36 DAS just two Ukrainian genotypes which characterized also high ANTH and MFI indexes has been kept tendency to increase SFR index - F. esculentum cv. Rubra and F. esculentum cv. Karadag. The Chinese genotypes shown decreasing of SFR index on 36 DAS with farther deacresing at 51 DAS of flowering stage with parallel increasing of ANTH, FLAV and MFI indexes.

\section{Total phenolics and anthocyanins estimation}

The biochemical analysis among experimental buckwheat genotypes of different origin has been shown that highest total phenolic contents was found in Ukrainian

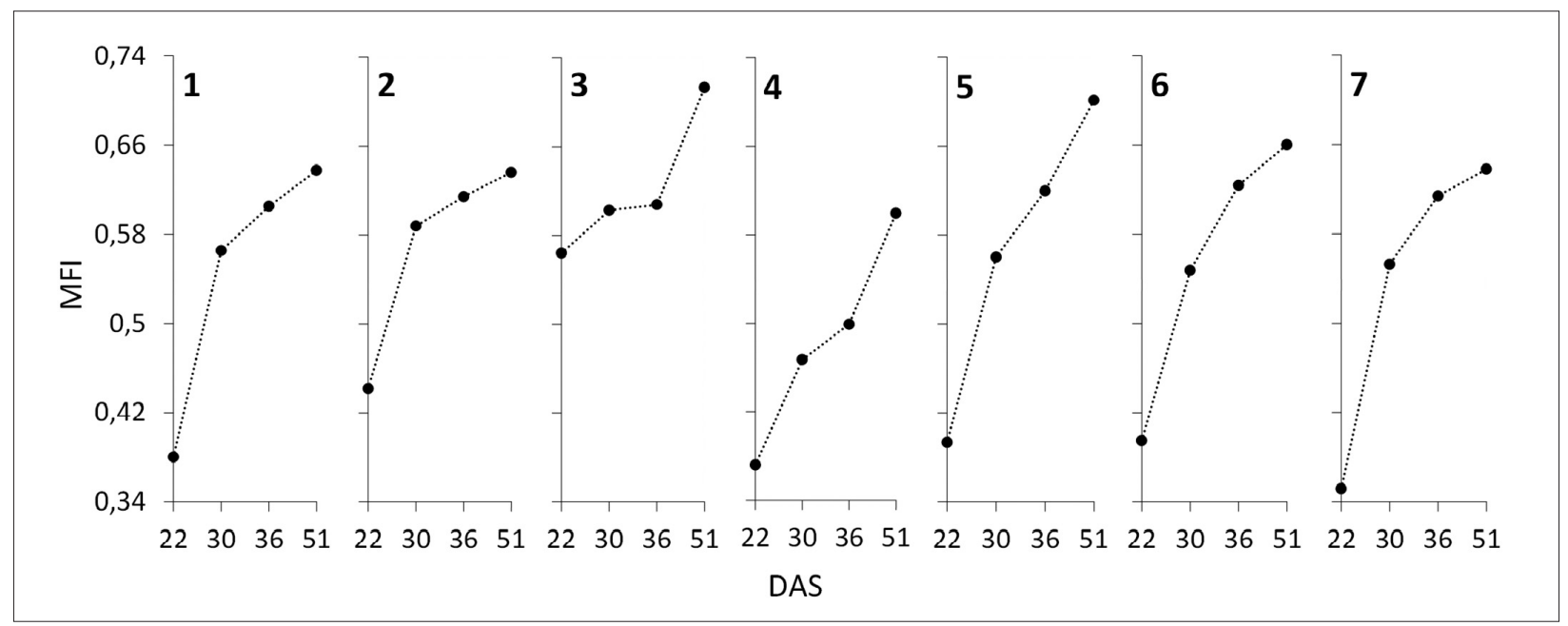

Figure 3. Values of MFI index in the leaves of investigated buckwheat plant species exposed to direct sunlight during 51 days after seedlings (numbers indicate individual cultivars of buckwheat as follow: 1 - F. tataricum rotundatum, 2 - F. tataricum himalaicum, 3 - F. esculentum cv. Rubra, 4 - F. esculentum cv. Karadag, 5 - F. esculentum cv. SuQiao 1, 6 - F. esculentum cv. YuQiao 4, 7 - F. esculentum cv. NingQiao 1). 


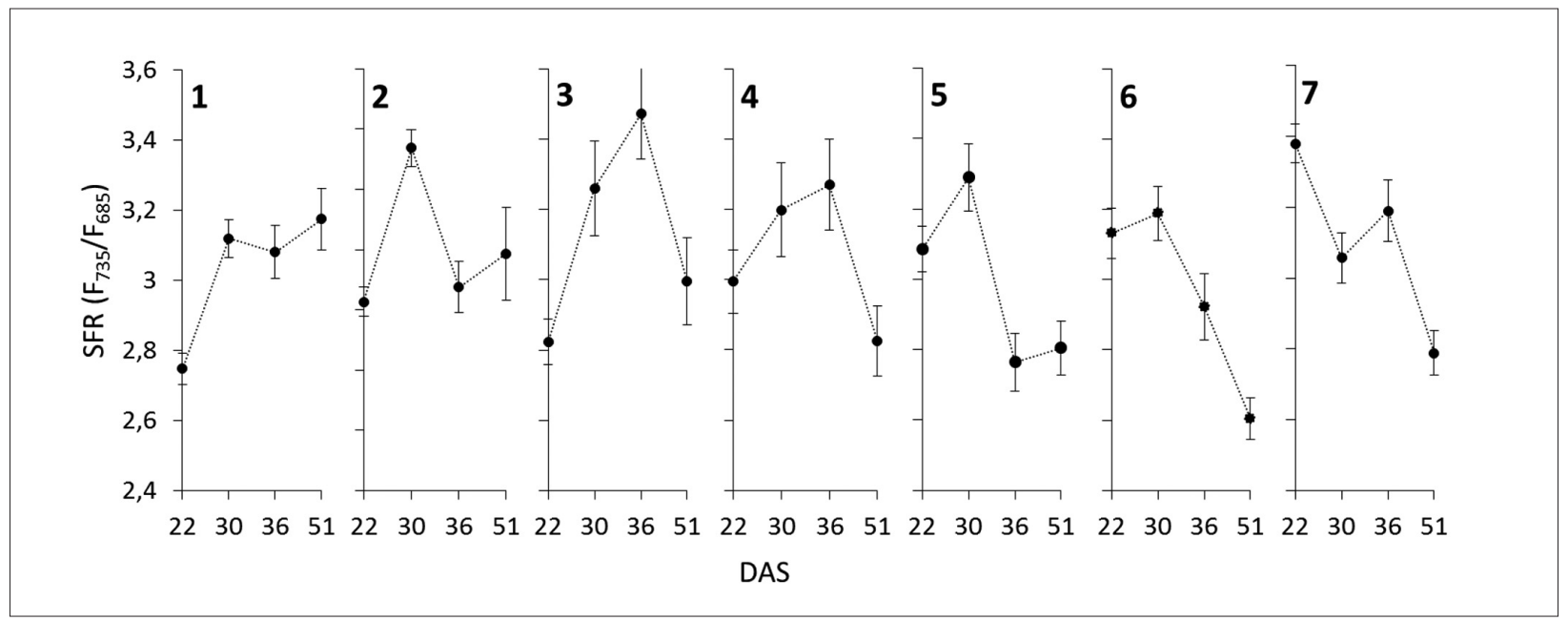

Figure 4. Values of SFR (simple fluorescence ratio) in the leaves of investigated buckwheat plant species exposed to direct sunlight during 51 days after seedlings (numbers indicate individual cultivars of buckwheat as follow: 1 - F. tataricum rotundatum, 2 - F. tataricum himalaicum, 3 - F. esculentum cv. Rubra, 4 - F. esculentum cv. Karadag, 5 - F. esculentum cv. SuQiao 1, 6 - F. esculentum cv. YuQiao 4,7 F. esculentum cv. NingQiao 1).

buckwheat Fagopyrum esculentum cv. Rubra and Chinese genotypes (Figure 5). At the same time leaves of Ukrainian Fagopyrum esculentum cv. Rubra has been characterized by highest anthocyanins content compared to the other experimental buckwheat genotypes of different origin. This data is connected with previous research where was studied role of anthocyanins as marker for selection of buckwheat plants with high rutin content in Fagopyrum esculentum cv. Rubra (Sytar et al. 2014).

\section{Analysis of hydroxycinnamic acid derivatives}

HPLC prescreening buckwheat genotypes of different origin on (51 DAS) has been identified chlorogenic, $p$-coumaric, $p$-anisic, cinnamic, methoxycinnamic, ferulic and vanilic acids. It was found highest content of chlorogenic and p-coumaric acids in the Chinese genotypes F. esculentum cv. NingQiao 1 and F. esculentum cv. YuQiao 4. The highest p-anisic acid content was found for buckwheat genotypes of F. tataricum himalaicum

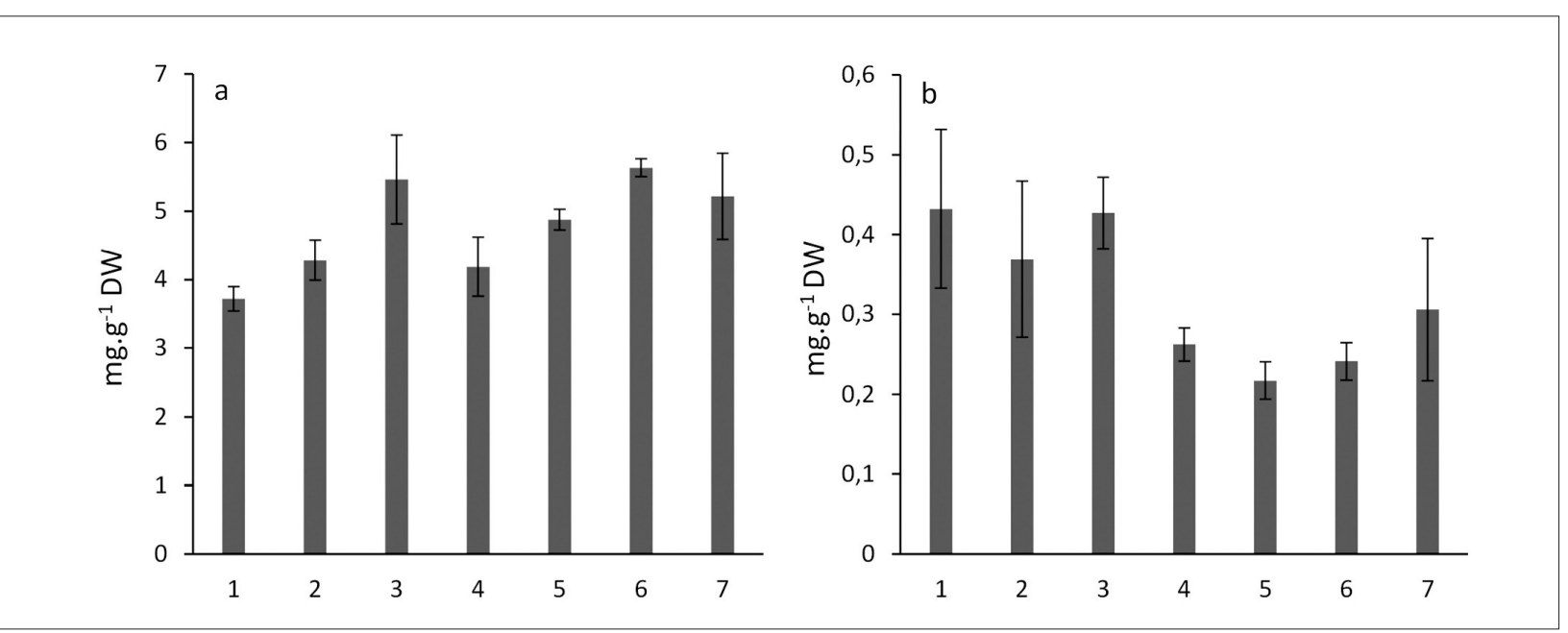

Figure 5. Content of total phenolics (5a) and anthocynanins (5b) in the buckwheat leaves determined by HPLC method (numbers indicate individual cultivars of buckwheat as follow: 1 - F. tataricum rotundatum, 2 - F. tataricum himalaicum, 3 - F. esculentum cv. Rubra, 4 F. esculentum cv. Karadag, 5 - F. esculentum cv. SuQiao 1, 6 - F. esculentum cv. YuQiao 4, 7 - F. esculentum cv. NingQiao 1) 
Sytar et al., (2019): Methodology in comparative physiology of buckwheat

\begin{tabular}{l|c|c|c|c|c|c|c}
\hline \multicolumn{1}{|c|}{ Leaves of buckwheat } & $\begin{array}{c}\text { chl. } \\
\text { acid }\end{array}$ & $\begin{array}{c}\text { p-coum. } \\
\text { acid }\end{array}$ & $\begin{array}{c}\text { p-anis. } \\
\text { acid }\end{array}$ & $\begin{array}{c}\text { cinn. } \\
\text { acid }\end{array}$ & $\begin{array}{c}\text { Methox. } \\
\text { acid }\end{array}$ & $\begin{array}{c}\text { fer. } \\
\text { acid }\end{array}$ & $\begin{array}{c}\text { van. } \\
\text { acid }\end{array}$ \\
\hline F. tataricum rotundatum & $0.4 \pm 0.1$ & $8.4 \pm 0.2$ & $0.6 \pm 0.0$ & $0.0 \pm 0.0$ & $0.8 \pm 0.2$ & $0.2 \pm 0.0$ & $0.1 \pm 0.0$ \\
\hline F. tataricum himalaicum & $0.3 \pm 0.0$ & $0.2 \pm 0.1$ & $0.8 \pm 0.1$ & $0.0 \pm 0.0$ & $2.6 \pm 0.1$ & $0.2 \pm 0.0$ & $0.1 \pm 0.0$ \\
\hline F. esculentum cv. Rubra & $0.1 \pm 0.0$ & $9.4 \pm 0.3$ & $0.0 \pm 0.0$ & $0.4 \pm 0.1$ & $11.2 \pm 2.8$ & $0.5 \pm 0.1$ & $0.5 \pm 0.0$ \\
\hline F. esculentum cv. Karadag & $0.2 \pm 0.0$ & $9.4 \pm 0.8$ & $0.0 \pm 0.0$ & $0.1 \pm 0.1$ & $4.8 \pm 0.6$ & $2.2 \pm 0.3$ & $0.2 \pm 0.0$ \\
\hline F. esculentum cv. SuQiao 1 & $0.3 \pm 0.1$ & $20.1 \pm 8.3$ & $0.1 \pm 0.0$ & $0.0 \pm 0.0$ & $3.0 \pm 0.3$ & $0.2 \pm 0.1$ & $0.3 \pm 0.0$ \\
\hline F. esculentum cv. YuQiao 4 & $0.4 \pm 0.1$ & $21.2 \pm 5.0$ & $0.0 \pm 0.0$ & $0.0 \pm 0.0$ & $2.4 \pm 0.1$ & $0.2 \pm 0.0$ & $0.2 \pm 0.0$ \\
\hline F. esculentum cv. NingQiao 1 & $0.5 \pm 0.0$ & $25.1 \pm 0.6$ & $0.1 \pm 0.1$ & $0.0 \pm 0.0$ & $4.0 \pm 0.3$ & $0.1 \pm 0.0$ & $0.3 \pm 0.0$ \\
\hline
\end{tabular}

Table 1. Content of phenolic acids identified via HPLC analysis in the experimental buckwheat samples

(Table 1). It is important to admit that genotypes of $F$. tataricum characterized by higher $\mathrm{p}$-anisic acid content compared to the experimental genotypes of F. esculentum of both origins.

The nondestructive technique of infrared spectroscopy is recommended as alternative technique for routine analysis of main flavonoids like rutin, quercetin and quercitrin in aerial parts of buckwheat (Ladan et al. 2017). It can be pointed out that individual bioactive compounds compositions are suitable indicators of the physiological stage of crop plants.

The phenotype of a plant is the result of a complex interaction between morphological, ontogenetical, physiological, and biochemical factors (Gratani 2014). The highest increasing of FLAV index has been observed on 51 DAS of flowering stage which is connected with flavonoids content in the Chinese genotypes. Rutin content of the grain of 22 buckwheat genotypes (F. esculentum and F. tataricum) grown in same region of origin had variation (Bai et al. 2009), so its important to use non-destructive methods for prescrening of flavonoids content for different genotypes. The high FLAV index at the flowering stage was not depended on flavonoids content on the beginning of seedlings stage (22 DAS).

Other investigated genotypes for ANTH index in range from 0.39 to $0.43 \mathrm{RU}$ at the beginning of seedlings stage. Genotypes of F. tataricum compared to the genotypes of $F$. esculentum of both origin shown decreasing of ANTH index during seedling growth. Liu et al. (2008) have shown that ethanol extracts of Tartary buckwheat sprouts had higher free radical scavenging activity and superoxide anion scavenging activity than those of common buckwheat sprouts (Liu et al. 2008). Total phenolics and rutin in tested samples were related to the antioxidant activities (Holasova et al. 2002).

The SFR index is linked to the Chl concentration of leaves (Diago et al. 2016). Leaf Chl and FLAV concentration on a surface basis depends on leaf age and the amount of light radiation received during their development. Both increase with leaf expansion and light exposure until veraison, while afterwards, leaf Chl usually decreases (Louis et al. 2009) while FLAV remain unvaryingly high (Downey et al. 2003). Such tendency has been confirmed in the our experiments with buckwheat genotypes of different origin just development of SFR index changes was different between Ukrainian and Chinese genotypes origin.

The antioxidant capacity can be connected with total phenolic and anthocyanin contents and variety of plant species plus maturity (Prior et al. 1998; Kim et al. 2003). Flavonoids and phenolic acids have relevant antioxidant properties (Barriada-Bernal et al. 2014). The concentration is affected by environmental conditions, age, and phenological stage (Almaraz-Abarca et al. 2013), while the qualitative phenolic profiles are more stable and vary among different groups of plants with a species-specific tendency (Emerenciano et al. 2001).

It was observed that presence of $p$-anisic acid was typical for F. tataricum genotypes compared to the experimental genotypes of F. esculentum of both origins Ukrainian and Chinese. p-anisic acid is one of the isomers of anisic acid which has antiseptic properties (Bhimba et 
al. 2010). It is also used as an intermediate in the preparation of more complex organic compounds.

Cinnamic acid has low toxicity and in the search for novel pharmacologically active compounds, cinnamic acid derivatives are important and promising compounds with high potential for development into drugs (Sova 2012). The high content of cinnamic acid at $52 \mathrm{~d}$ of flowering period found in Ukrainian F. esculentum cv. Rubra, which is characterized by high anthocyanins content. In plants, flavanone biosynthesis begins with the hydroxylation of cinnamic acid to $p$-coumaric acid by a membrane-bound P450 monooxygenase, cinnamate 4-hydroxylase (C4H) (Yan et al. 2005). At 52 day of flowering period the $p$-coumaric acid content was higher more than 2 times in Chinese genotypes compared to the Ukrainian genotypes of F. esculentum.

\section{CONCLUSION:}

The screening of biological active compounds of phenolic nature in the early stages of growth with non-destructive chlorophyll fluorescence techniques can be used for qualitative traits analysis of plant sprouts, especial- ly buckwheat. The high flavonoids level at the flowering stage is not dependent on flavonoids content on the begging of seedlings stage. Plant genotypes of different origin can vary in flavonoid, anthocyanins and pigments content during stages of growth but changes in their contents can be similar for representatives of the same origin. The presence of some phenolic acid can be typical for genotypes of F. tataricum compared to the genotypes of F. esculentum. To support natural plant biodiversity research it would be good to develop use of fast pre-screening methods of plants during all stages of development what can be helpful in applied food plant research.

Abbreviations: FLAV- flavonoids, ANTH - anthocyanins, SFR - simple fluorescence ratio, Chl - chlorophyll, DAS - days after sowing

\section{ACKNOWLEDGEMENTS}

This work was supported by EC under the project no. 26220220180: "Construction of the "AgroBioTech" Research Centre" and projects APVV-15-0721

\section{REFERENCES}

Abuajah, C.I., Ogbonna, A.C., Osuji, C.M. 2015. Functional components and medicinal properties of food: a review. J Food Sci Technol 52: 2522-2529. doi: 10.1007/s13197-014-1396-5.

Agati, G., Cerovic, Z.G., Pinelli, P., Tattini, M. 2011. Light-induced accumulation of ortho-dihydroxylated flavonoids as non-destructively monitored by chlorophyll fluorescence excitation techniques. Environ Exp Botany 73: 3-9. doi:10.1016/j.envexpbot.2010.10.002

Alexandratos, N. and J.Bruinsma, 2012. World Agriculture: Towards 2030/2050. The 2012 revision. ESA Working Paper No. 12-03 (Food Agric Org, Rome).

Almaraz-Abarca, N., González-Elizondo, M.S., Campos, M.G., Ávila-Sevilla, Z.E., Delgado-Alvarado, E.A., Ávila-Reye,s J.A. 2013. Variability of the foliar phenol profiles of the Agave victoriae-reginae complex (Agavaceae). Bot Sci 91: 295306. doi:10.17129/botsci.9

Bai, C.Z., Feng, M.L., Hao, X.L., Zhong, Q.M., Tong, L.G., Wang, Z.H. 2015. Rutin, quercetin, and free amino acid analysis in buckwheat (Fagopyrum) seeds from different locations. Genet Mol Res 14: 19040-19048. doi: 10.4238/2015. December.29.11

Barriada-Bernal, L.G., Almaraz-Abarca, N., Delgado-Alvarado, E.A., Gallardo-Velázquez, T., Ávila-Reyes, J.A., Torrres-Morán, M.I., González-Elizondo, M.S., Herrera-Arrieta, Y. 2014. Flavonoid composition and antioxidant capacity of the edible flowers of Agave durangensis (Agavaceae). CyTA - J Food 12: 105-114. doi:10.1080/19476337.2013.8 01037

Bhimba, V., Meenupriya, J., Joel, E.L., Naveena, D.E., Kumar, S., Thangaraj, M. 2010. Antibacterial activity and characterization of secondary metabolites isolated from mangrove plant Avicennia officinalis. Asian Pac J Trop Biomed 3: 544-546. doi:10.1016/S1995-7645(10)60131-9

Burchard, P., Bilger, W., Weissenböck, G. 2000. Contribution of hydroxycinnamates and flavonoids to epidermal shielding of UV-A and UV-B radiation in developing rye primary leaves as assessed by ultraviolet-induced chlorophyll fluorescence measurements. Plant Cell Environ 23: 1373-1380. doi:10.1046/j.1365-3040.2000.00633.x 
Sytar et al., (2019): Methodology in comparative physiology of buckwheat

Cerovic, Z.G., Ounis, A., Cartelat, A., Latouche, G., Goulas, Y., Meyer, S., Moya, I. 2002. The use of chlorophyll fluorescence excitation spectra for the nondestructive in situ assessment of UV-absorbing compounds in leaves. Plant Cell Environ 25: 1663-1676. doi: 10.1046/j.1365-3040.2002.00942.x

Diago, M.P., Rey-Carames, C., Le Moigne, M., Fadaili, E.M., Tardaguila, J., Cerovic, Z.G. 2016. Calibration of non-invasive fluorescence-based sensors for the manual and on-the-go assessment of grapevine vegetative status in the field. Aust J Grape Wine R 22: 438-449. doi: 10.1111/ajgw.12228

Downey, M.O., Harvey, J.S., Robinson, S.P. 2003. Synthesis of flavonols and expression of flavonol synthase genes in developing grape berries of Shiraz and Chardonnay (Vitis vinifera L.). Aust J Grape Wine R 9: 110-121. doi:10.1111/j.1755-0238.2003.tb00261.x

Emerenciano, V.P., Militão, J.S., Campos, C.C., Romoff, P., Kaplan, M.A., Zambon, M., Brantm, A.J. 2001. Flavonoids as chemotaxonomic markers for Asteraceae. Biochem Syst Ecol 29: 947-957. doi:10.1016/S0305-1978(01) 00033-3

Ghozlen, N.B., Cerovic, Z.G., Germain, C., Toutain, S., Latouche, G. 2010. Non-destructive optical monitoring of grape maturation by proximal sensing. Sensors 10: 10040-10068. doi: 10.3390/s101110040

Gratani, L. 2014. Plant phenotypic plasticity in response to environmental factors. Advances in Botany 2014: 1-7. doi: $10.1155 / 2014 / 208747$

Holasova, M., Fiedlerova, V., Smrcinova, H., Orsak, M., Lachman, J., Vavreinova, S. 2002. Buckwheat- the source of antioxidant activity in functional foods. Food Res Int 35: 207-211. doi:10.1016/S0963-9969(01)00185-5

Kim, D.O., Jeong, S.W., Lee, C.Y. 2003. Antioxidant capacity of phenolic phytochemicals from various cultivars of plums. Food Chem 81: 321-326. doi:10.1016/S0308-8146(02)00423-5

Krotov, A., Dranenko, E. 1973. Amphidiplod buckwheat. Rep Inst Plant Ind 3: 41-44.

Ladan, M.K., Straus, J., Tavčar Benković, E., Kreft, S. 2017. FT-IR-based method for rutin, quercetin and quercitrin quantification in different buckwheat (Fagopyrum) species. Sci Rep 7: 7226. doi:10.1038/s41598-017-07665-z

Liu, C.L., Chen, Y.S., Yang, J.H., Chiang, B.H. 2008. Antioxidant activity of tartary (Fagopyrum tataricum (L.) Gaertn.) and common (Fagopyrum esculentum moench) buckwheat sprouts. J Agric Food Chem. 56: 173-8. doi: 10.1021/ jf072347s

Louis, J., Meyer, S., Maunoury-Danger, F., Fresneau, C., Meudec, E., Cerovic, Z.G. 2009. Seasonal changes in optically assessed epidermal phenolic compounds and chlorophyll contents in leaves of sessile oak (Quercus petraea Matt. (Liebl.)): towards signatures of phenological stage. Funct Plant Biol 36: 732-741. doi: 10.1071/FP09010

Mewis, I,. Smetanska, I.M., Müller, C.T., Ulrichs, C. 2010. Specific polyphenolic compounds in cell culture of Vitis vinifera L. cv. Gamay Fréaux. Appl Biochem Biotechnol 164: 148-161. doi: 10.1007/s12010-010-9122-x

Ounis, A., Cerovic, Z.G., Briantais, J.M., Moya, I. 2001. DE-FLIDAR: a new remote sensing instrument for estimation of epidermal UV absorption in leaves and canopies. Proceedings of European Association of Remote Sensing Laboratories 1: 196-204.

Prior, R.L., Cao, G., Martin, A., Sofic, E., McEwen, J., O’Brien, C., Lischner, N., Ehlenfeldt, M., Kalt, W., Krewer, G., Mainland, C.M. 1998. Antioxidant capacity as influenced by total phenolic and anthocyanin content, maturity, and variety of Vaccinium species. J Agric Food Chem 46: 2686-2693. doi: 10.1021/jf980145d

Saturni, L., Ferretti, G., Bacchetti, T. 2010. The gluten-free diet: safety and nutritional quality. Nutrients 2: 16-34. doi: 10.3390/nu20100016

Singleton, V.L., Rossi, J.A. 1965. Colorimetry of total phenolics with phosphomolybdic-phosphotungstic acid reagents. Am J Enol Vitic 16: 144-158.

Sytar, O., Kosyan, A., Taran, N., Smetanska, I. 2014. Antocyanins as marker for selection of buckwheat plants with high rutin content. Gesunde Pflanzen 66: 165-169. doi: 10.1007/s10343-014-0331-z

Sytar, O. 2015. Characterisation of functional food market in Ukraine and reasons for its development. Proceedings of International Scientific Conference "Quality of tourist services and promotion of healthy lifestyle", 27-28 $8^{\text {th }}$ May 2015. The University of Life Sciences in Lublin, Poland, 75-84.

Sytar, O., Brestic, M., Zivcak, M., Tran, L.-S. 2016. The contribution of buckwheat genetic resources to health and dietary diversity. Curr Genom 17: 193-206. doi: 10.2174/1389202917666160202215425 
Fagopyrum 36(1):11-21 (2019)

Sytar, O., Brestic, M., Zivcak, M., Olsovska, K., Kovar, M., Shao, H., He, X. 2017. Applying hyperspectral imaging to explore natural plant diversity towards improving salt stress tolerance. Sci Total Environ 578: 90-99. doi: 10.1016/j. scitotenv.2016.08.014

Sytar, O., Bruckova, K., Hunkova, E., Zivcak, M., Kiessoun, K., Brestic, M. 2015. The application of Multiplex flourimetric sensor for analysis flavonoids content in the medical herbs family Asteraceae, Lamiaceae, Rosaceae. Biol Res 48: 1-7. doi: 10.1186/0717-6287-48-5

Varzakas, T., Zakynthinos, G., Verpoort, F. 2016. Plant food residues as a source of nutraceuticals and functional foods. Foods 5: 88. doi: 10.3390/foods5040088

Verhoeven, H.A., de Vos, C.R., Bino, R.J., Hall, R.D. 2006. Plant metabolomics strategies based upon quadrupole time of flight mass spectrometry (QTOF-MS). In Saito K, Willmitzer L, editors. Biotechnology in agriculture and forestry. Berlin: Springer. p. 33-48.

Yan, Y., Kohli, A., Koffas Mattheos, A.G. 2005. Biosynthesis of Natural Flavanones in Saccharomyces cerevisiae. Appl Environ Microbiol 71: 5610-5613. doi: 10.1128/AEM.71.9.5610-5613.2005

Zivcak, M., Brückova, K., Sytar, O., Brestic, M., Olsovska, K., Allakhverdiev, S.I. 2017. Lettuce flavonoids screening and phenotyping by chlorophyll fluorescence excitation ratio. Planta 245: 1215-1229. doi: 10.1007/s00425-017-2676-x

\section{IZVLEČEK}

Predstavljeni so nedestruktivni načini ugotavljanja flavonoidov, antocianinov in pigmentov tekom osebkovega razvoja pri genotipih ajde različnega izvora, do faze cvetenja. Podobno naraščanje indeksov FLAV, ANTH in MFI je bilo ugotovljeno pri kitajskih in ukrajinskih genotipih. Genotipi Fagopyrum tataricum so v primerjavi z genotipi F. esculentum imeli tekom rasti kalic nižji indeks ANTH. Indeks SFR, povezan s koncentracijo klorofila je kazal različno dinamiko v primerjavi genotipov iz Ukrajine in Kitajske. V srednji fazi (30 dni po setvi) je bil pri večini genotipov ugotovljen povečan indeks SFR. Na 36 dan po setvi sta dva ukrajinska genotipa z visokima indeksoma ANTH in MFI imela naraščajoč indeks SFR. HPLC analize raziskanih vzorcev so pokazale vsebnost $p$-anisinske kisline, značilne za F. tataricum v primerjavi s kultivarji F. esculentum. Rastline genotipov ajde lahko imajo različno vsebnost flavonoidov, antocianinov in pigmentov tekom faz rasti in razvoja, vendar podobne vsebnosti pri vzorcih enakega porekla. 